\title{
Article \\ Cognitive Impairment in Frail Hypertensive Elderly Patients: Role of Hyperglycemia
}

\author{
Pasquale Mone ${ }^{1,2,3, *}$, Jessica Gambardella ${ }^{3,4}$, Antonella Pansini ${ }^{1}$, Antonio de Donato ${ }^{2}$ (D), Giuseppe Martinelli ${ }^{5}$, \\ Eugenio Boccalone ${ }^{6}$, Alessandro Matarese ${ }^{7}$, Salvatore Frullone ${ }^{1}$ and Gaetano Santulli ${ }^{3,4,8, * \text { (D) }}$
}

Citation: Mone, P.; Gambardella, J.; Pansini, A.; de Donato, A.; Martinelli, G.; Boccalone, E.; Matarese, A.; Frullone, S.; Santulli, G. Cognitive Impairment in Frail Hypertensive Elderly Patients: Role of

Hyperglycemia. Cells 2021, 10, 2115 https://doi.org/10.3390/cells1008 2115

\section{Academic Editors:}

Alessandro Attanzio, Erica Buoso and Fabrizio Biundo

Received: 8 June 2021

Accepted: 13 August 2021

Published: 17 August 2021

Publisher's Note: MDPI stays neutral with regard to jurisdictional claims in published maps and institutional affiliations.

Copyright: (c) 2021 by the authors. Licensee MDPI, Basel, Switzerland. This article is an open access article distributed under the terms and conditions of the Creative Commons Attribution (CC BY) license (https:// creativecommons.org/licenses/by/ $4.0 /)$.
1 ASL Avellino, 83100 Avellino, Italy; antonellapansini87@gmail.com (A.P.); sfrullone@libero.it (S.F.)

2 Department of Mental and Physical Health and Preventive Medicine, University of Campania "Luigi Vanvitelli", 80121 Naples, Italy; antoniodedonato88@gmail.com

3 Department of Medicine (Cardiology), Wilf Family Cardiovascular Research Institute, Fleischer Institute for Diabetes and Metabolism (FIDAM), Albert Einstein College of Medicine, New York, NY 10461, USA; gambardellajessica@gmail.com

4 International Translational Research and Medical Education Consortium (ITME), University "Federico II" of Naples, 80131 Naples, Italy

5 ASL Naples, 80100 Naples, Italy; peppemartinelli85@gmail.com

ASL Caserta, 81100 Caserta, Italy; eugeniob.85@gmail.com

Cardarelli Hospital, 80131 Naples, Italy; alessandromatarese@yahoo.it

8 Department of Molecular Pharmacology, Einstein Institute for Aging Research, Einstein-Sinai Diabetes Research Center (ES-DRC), Albert Einstein College of Medicine, New York, NY 10461, USA

* Correspondence: pasquale.mone@unicampania.it (P.M.); gaetano.santulli@einsteinmed.org (G.S.)

\begin{abstract}
Endothelial dysfunction is a key hallmark of hypertension, which is a leading risk factor for cognitive decline in older adults with or without frailty. Similarly, hyperglycemia is known to impair endothelial function and is a predictor of severe cardiovascular outcomes, independent of the presence of diabetes. On these grounds, we designed a study to assess the effects of high-glucose and metformin on brain microvascular endothelial cells (ECs) and on cognitive impairment in frail hypertensive patients. We tested the effects of metformin on high-glucose-induced cell death, cell permeability, and generation of reactive oxygen species in vitro, in human brain microvascular ECs. To investigate the consequences of hyperglycemia and metformin in the clinical scenario, we recruited frail hypertensive patients and we evaluated their Montreal Cognitive Assessment (MoCA) scores, comparing them according to the glycemic status (normoglycemic vs. hyperglycemic) and the use of metformin. We enrolled 376 patients, of which 209 successfully completed the study. We observed a significant correlation between MoCA score and glycemia. We found that hyperglycemic patients treated with metformin had a significantly better MoCA score than hyperglycemic patients treated with insulin $(18.32 \pm 3.9$ vs. $14.94 \pm 3.8 ; p<0.001)$. Our in vitro assays confirmed the beneficial effects of metformin on human brain microvascular ECs. To our knowledge, this is the first study correlating MoCA score and glycemia in frail and hypertensive older adults, showing that hyperglycemia aggravates cognitive impairment.
\end{abstract}

Keywords: aging; antidiabetic drugs; metformin; endothelial cells; cognitive impairment; frailty; hypertension; hyperglycemia; anti-aging research; therapeutic strategies; age-related disease; metabolism

\section{Introduction}

Hypertension is one of the most common comorbidities, and is a recognized leading risk factor for cognitive decline [1-8]. Hypertension leads to chronic endothelial dysfunction, disrupting the integrity of endothelial cells (ECs) and contributing to oxidative stress, inflammation, and atherosclerosis [9-16].

Hyperglycemia (HG) is common in patients suffering from cardiovascular diseases [17], is an established independent predictor of severe outcomes, even in absence of frank dia- 
betes mellitus (DM) $[18,19]$, and has been proposed to exacerbate endothelial dysfunction in hypertensive subjects [20-32].

Frailty is a multidimensional condition due to reserve loss leading to both physical and cognitive impairment [33,34]. Frail older adults present a high-risk of adverse events including disability, hospitalization, and mortality [35]. Hence, it is very important to evaluate comorbidities and complications in order to reduce the incidence of cognitive and physical impairment; a thorough clinical assessment remains among the main strategies to obtain an early diagnosis (as well as a timely treatment) of cognitive impairment [36-43].

Metformin is an oral antidiabetic drug and its potential role in contrasting endothelial dysfunction and cognitive impairment currently represents a hot topic [44-47]; a recent trial on 80 subjects with mild cognitive impairment has shown significant improvements in verbal memory scores [48]; other investigators have underlined its beneficial effects, especially in older adults [47,49-52].

On these grounds, we aim to investigate the effects of HG and metformin on cognitive impairment in frail hypertensive patients and, in vitro, on human brain ECs.

\section{Materials and Methods}

\subsection{Patients}

We enrolled consecutive frail hypertensive elderly patients presenting to the ASL (local health providers managed by the Italian Ministry of Health) located in Avellino, Caserta, and Naples, Italy from April 2019 to April 2021. The following inclusion and exclusion criteria were applied:

\section{Inclusion criteria:}

1. A previous diagnosis of hypertension with no clinical or laboratory evidence of secondary causes;

2. Age > 65 years;

3. A frail status.

\section{Exclusion criteria:}

1. Age $<65$ years;

2. Absence of frail status;

3. Absence of hypertension;

4. Left ventricular ejection fraction $<25 \%$, previous myocardial infarction, previous revascularization, or previous fibrinolytic therapy.

All patients underwent blood pressure measurement and blood analysis to assess glycemia. HG was defined by values $\geq 140 \mathrm{mg} / \mathrm{dL}$, according to the American Diabetes Association [53]. Hypertension was defined as systolic blood pressure (SBP) $\geq 140 \mathrm{~mm}$ $\mathrm{Hg}$, and/or diastolic blood pressure (DBP) $\geq 90 \mathrm{~mm} \mathrm{Hg}$ on repeated measurements, or chronically treated hypertension with antihypertensive medications [54].

Based on glycemic values and medical treatment, we divided our population in the following four groups:

- $\quad$ Normoglycemic (NG) patients without DM (n: 51)

- $\quad$ NG patients with DM (n: 55)

- $\quad$ Metformin-treated HG patients (n: 53)

- $\quad$ Insulin-treated HG patients (n: 50)

\subsection{Assessment of Cognitive Function}

Cognitive function was assessed using the Montreal Cognitive Assessment (MoCA) test, which has been shown to be specific for the evaluation of cognitive domains (attention, concentration, memory, language, calculation, orientation and executive functions), and is generally considered one of the best tests to detect mild cognitive impairment [55-57]. 


\subsection{Frailty Evaluation}

A physical frailty assessment was performed following the Fried criteria [34,37]. A diagnosis of frailty status was made with at least three of the following five points:

- Weight loss (unintentional loss of $\geq 4.5 \mathrm{~kg}$ in the past year);

- Weakness (handgrip strength in the lowest $20 \%$ quintile at baseline, adjusted for sex and body mass index (BMI);

- $\quad$ Exhaustion (poor endurance and energy, self-reported);

- Slowness (walking speed under the lowest quintile adjusted for sex and height);

- Low physical activity level (lowest quintile of kilocalories of physical activity during the past week).

\subsection{In Vitro Experiments}

Human brain microvascular ECs were obtained from Neuromics (Minneapolis, MN, USA; catalog number: \#HEC02). Cells were cultured in a standard humidified atmosphere $\left(37^{\circ} \mathrm{C}\right)$ containing $5 \% \mathrm{CO}_{2}$, as we described [58]. In some experiments, cells were treated with metformin $(0.1,0.5$, and $1 \mathrm{mM})$, adding glucose at 5 or $25 \mathrm{mM}$, or mannitol $20 \mathrm{mM}$ as osmotic control, for $48 \mathrm{~h}$.

The endothelial permeability assay was performed as we described and validated [58, 59], using fibronectin-coated transwell filters (Corning Inc., Corning, NY, USA).

Levels of mitochondrial and cellular reactive oxygen species (ROS) were assessed using MitoSOX and CM-H ${ }_{2}$ DCFDA dyes, respectively, as we previously described $[60,61]$.

Cell death was evaluated using a Caspase-Glo ${ }^{\circledR} 3 / 7$ assay (Promega, Madison, WI, USA; catalog number: \#G6321), as we described [62]. All reagents were from MilliporeSigma (Burlington, MA, USA), unless otherwise stated. All experiments were conducted at least in triplicate by blinded investigators.

\subsection{Statistical Analysis}

Data are presented as mean \pm SD. In an a priori power analysis, we calculated the number of patients required for the study to reject the null hypothesis $95 \%$ of the time (i.e., with a one-tailed type II error rate of 0.05 ) and with a two-tailed type I error at a 0.05 level of significance; sample size was calculated using the G-POWER software, yielding a minimum n of 50 /group.

We applied a dispersion model correlating MoCA score and glycemia; we performed a linear regression analysis with MoCA score as dependent variable to explore the impact of comorbidities. For the in vitro assays, we applied the two-way ANOVA followed by Tukey-Kramer multiple comparison test.

Statistical significance was set at $p<0.05$ and calculations were computed using SPSS 26 and GraphPad Prism 9.1.1.

\section{Results}

\subsection{Population of Frail Hypertensive Patients}

We evaluated a total of 316 frail patients with hypertension; 31 patients were unwilling to provide clinical information, and 76 subjects did not fulfill the inclusion and exclusion criteria (Figure 1). Hence, 209 patients entered the study: 106 NG and 103 HG subjects.

There were no significant differences in mean age, BMI, sex distribution, smoking habits, and comorbidities between the two groups (Table 1). All patients were taking antihypertensive drugs; the use of diuretics, angiotensin-converting enzyme inhibitors, angiotensin receptors blockers, beta-blockers, and calcium blockers was similar between the two groups (Table 1). Comorbidities are reported in Table 1, as well. 


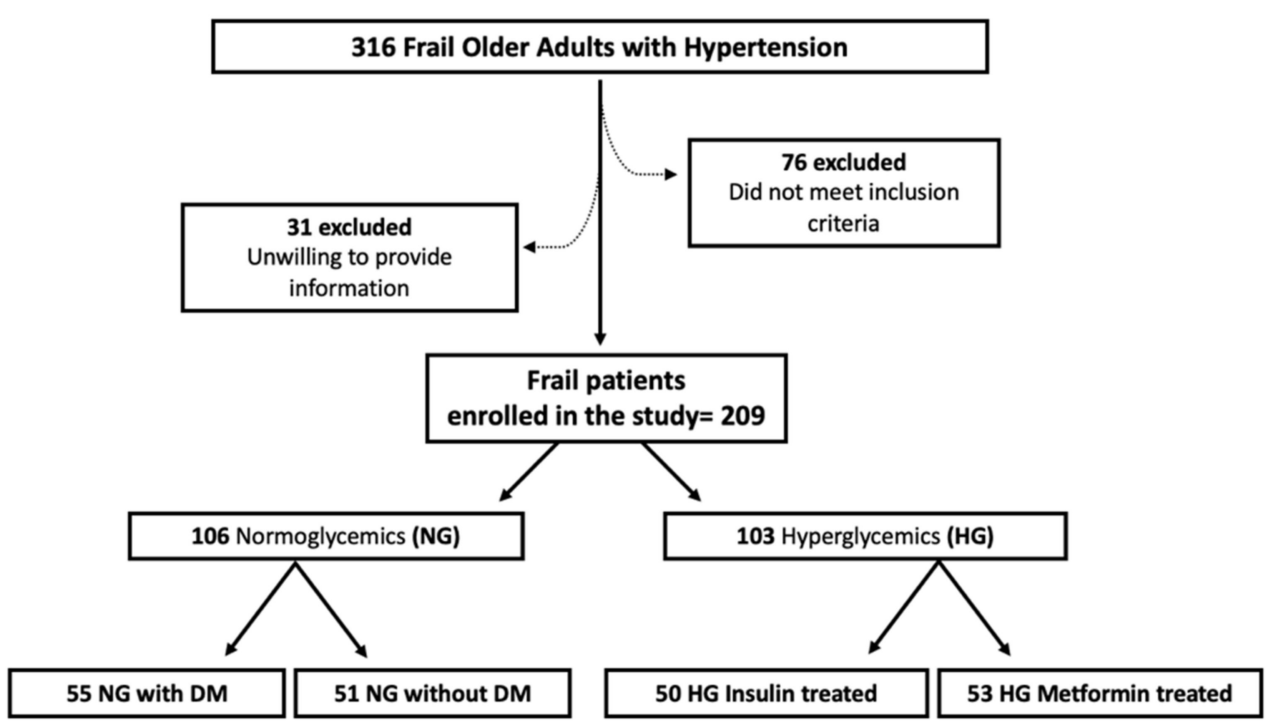

Figure 1. Study Flow Diagram. DM: diabetes mellitus; HG: hyperglycemic; NG: normoglycemic.

Table 1. Clinical characteristics of our population.

\begin{tabular}{|c|c|c|}
\hline & NG Patients & HG Patients \\
\hline $\mathrm{N}$ & 106 & 103 \\
\hline Mean age (years) & $75.0 \pm 6.5$ & $76.0 \pm 6.1$ \\
\hline BMI $\left(\mathrm{kg} / \mathrm{m}^{2}\right)$ & $27.1 \pm 1.9$ & $27.3 \pm 1.8$ \\
\hline $\mathrm{SBP}(\mathrm{mmHg})$ & $128.9 \pm 12.4$ & $129.2 \pm 11.8$ \\
\hline DBP (mmHg) & $78.8 \pm 6.6$ & $79.2 \pm 6.3$ \\
\hline Heart rate (bpm) & $87.5 \pm 8.3$ & $88.2 \pm 8.2$ \\
\hline \multicolumn{3}{|l|}{ Comorbidities } \\
\hline$\overline{\text { Diabetes, n (\%) }}$ & $56(52.0)$ & $103(100)$ \\
\hline Dyslipidemia, n (\%) & $66(63.0)$ & $66(64.0)$ \\
\hline $\mathrm{CVD}, \mathrm{n}(\%)$ & $29(30.0)$ & $31(30.5)$ \\
\hline COPD, n (\%) & $38(36.5)$ & $39(38.0)$ \\
\hline CKD n $(\%)$ & $43(41.0)$ & $44(43.0)$ \\
\hline Current smokers, n (\%) & $44(41.5)$ & $41(40.0)$ \\
\hline \multicolumn{3}{|l|}{ Active treatments } \\
\hline$\overline{\beta \text {-blockers, n (\%) }}$ & $61(58.0)$ & $57(56.0)$ \\
\hline ACE inhibitors, $\mathrm{n}(\%)$ & $73(69.0)$ & $70(68.0)$ \\
\hline Angiotensin receptor blockers, $\mathrm{n}(\%)$ & $35(33.0)$ & $33(32.0)$ \\
\hline Calcium inhibitors, $\mathrm{n}(\%)$ & $24(23.0)$ & $28(27.0)$ \\
\hline Statins, $\mathrm{n}(\%)$ & $57(54.0)$ & $54(53.0)$ \\
\hline Diuretics, n (\%) & $8(8.0)$ & $11(11.0)$ \\
\hline Aspirin, n (\%) & $46(44.0)$ & $50(49.0)$ \\
\hline \multicolumn{3}{|l|}{ Laboratory analyses } \\
\hline Plasma glucose (mg/dL) & $124.6 \pm 11.8$ & $207.3 \pm 18.6$ \\
\hline Total cholesterol (mg/dL) & $193.9 \pm 19.8$ & $192.6 \pm 20.2$ \\
\hline Creatinine $(\mathrm{mg} / \mathrm{dL})$ & $1.0 \pm 0.1$ & $1.0 \pm 0.1$ \\
\hline
\end{tabular}

ACE: angiotensin converting enzyme; BMI: body mass index; COPD: chronic obstructive pulmonary disease CKD: chronic kidney disease; CVD: cardiovascular disease; DBP: diastolic blood pressure; HG: hyperglycemic; NG: normoglycemic; SBP: systolic blood pressure.

\subsection{Glycemia Correlates with the MoCA Score in Frail Hypertensive Patients}

Comparing NG and HG patients, we observed a significantly compromised cognitive function in the latter group in terms of MoCA score (NG: $19.95 \pm 3.6$ vs. HG: $15.78 \pm 4.5$; $p<0.05)$. Furthermore, as depicted in Figure 2, we found a strong correlation between the MoCA score and blood glucose levels ( $\mathrm{r}:-0.611 ; p$ : <0.001). 


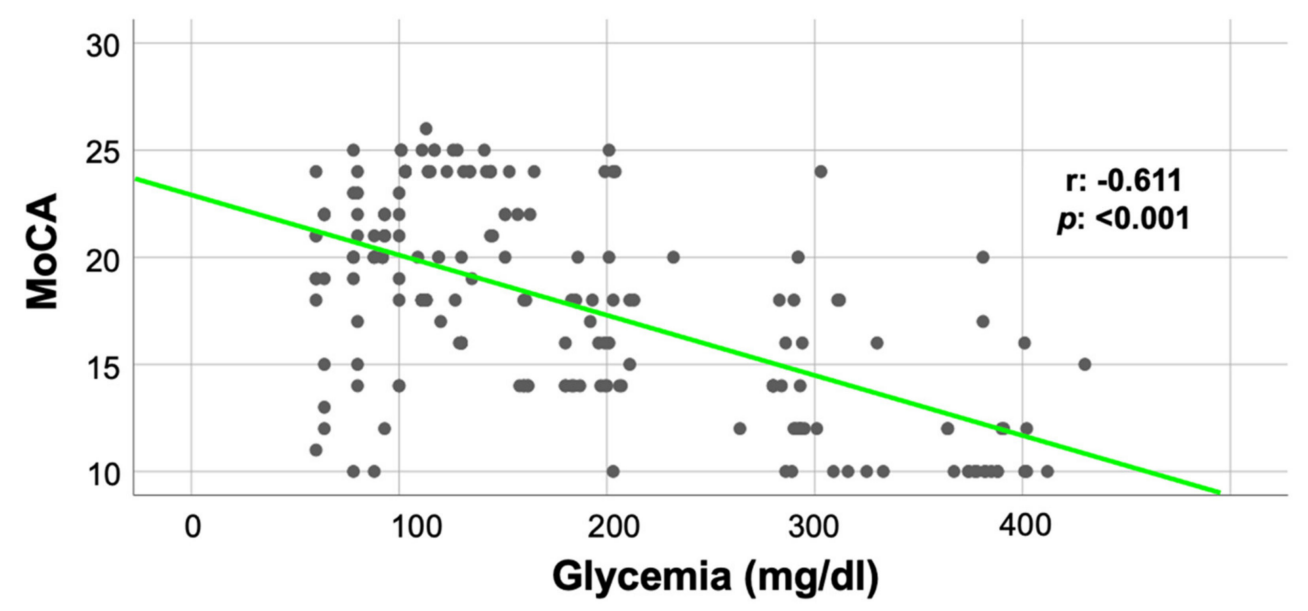

Figure 2. Correlation between MoCA score and glycemia.

To evaluate the impact of comorbidities on these findings, we performed a linear regression analysis using the MoCA score as dependent variable (Table 2). We observed a significant effect of age, diabetes, and cerebrovascular disease (CVD) $(p<0.001)$, alongside chronic kidney disease ( $p$ : 0.025).

Table 2. Linear regression analysis with the MoCA score as dependent variable.

\begin{tabular}{cccccc}
\hline & B & $\begin{array}{c}\text { Standard } \\
\text { Error }\end{array}$ & Beta & t & $p$ \\
\hline Age & -0.247 & 0.042 & -0.340 & -5.893 & $<0.001$ \\
Diabetes & -4.306 & 0.544 & -0.427 & -7.923 & $<0.001$ \\
CVD & -4.349 & 0.505 & -0.469 & -8.615 & $<0.001$ \\
Hyperlipidemia & -0.619 & 0.483 & -0.065 & -1.281 & 0.202 \\
CKD & -1.213 & 0.537 & -0.128 & -2.257 & 0.025 \\
COPD & 1.861 & 0.522 & 0.197 & 3.566 & 0.050 \\
\hline COPD. chronic obstructive pulmonary disease; CKD. chronic kidney disease. CVD. cardiovascular disease.
\end{tabular}

3.3. The MoCA Score Is Significantly Higher in HG Patients Treated with Metformin Than in HG Patients Treated with Insulin

In order to evaluate the effect of metformin treatment on the MoCA score, we divided our patients according to their glycemic status and drug treatment, as follows: metformintreated HG patients (MoCA score: $18.32 \pm 3.9$ ), insulin-treated HG patients (MoCA score: $14.94 \pm 3.8$ ), NG patients with DM (MoCA score: $17.45 \pm 3.1$ ), and NG patients without DM (MoCA score: $20.11 \pm 3.3$ ).

We found that the MoCA score in metformin-treated HG patients was significantly different from insulin-treated HG patients ( $p<0.001$, Figure 3$)$. 


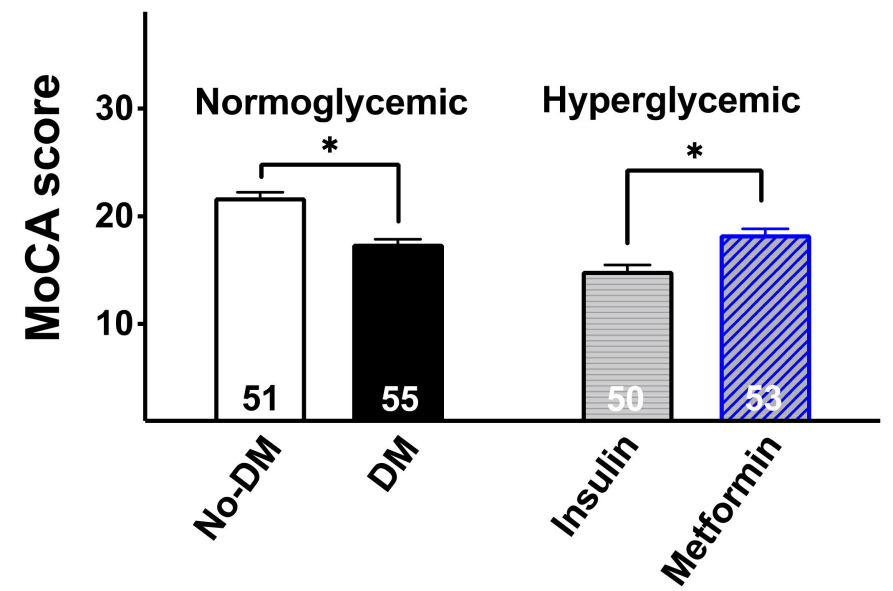

Figure 3. MoCA score in normoglycemic subjects without diabetes mellitus (No-DM), normoglycemic patients with diabetes mellitus (DM), hyperglycemic patients treated with insulin, and hyperglycemic patients treated with metformin. The number within each bar indicates the number of patients/group. Data are means $\pm \mathrm{SD} ; *$ : $p<0.05$.

\subsection{In Vitro Assays}

High glucose concentrations have been shown to elicit a leak of the endothelial permeability barrier $[63,64]$ and to increase ROS generation in ECs $[23,65]$. To test whether metformin could actually mitigate endothelial leakage and oxidative stress triggered by HG, we performed a series of in vitro dose-response experiments on human brain microvascular ECs. We found that metformin significantly attenuated the HG-induced endothelial leakage (Figure 4), reduced both mitochondrial (Figure 5A) and cellular (Figure 5B) ROS production, and prevented high-glucose-induced EC apoptosis (Figure 6).

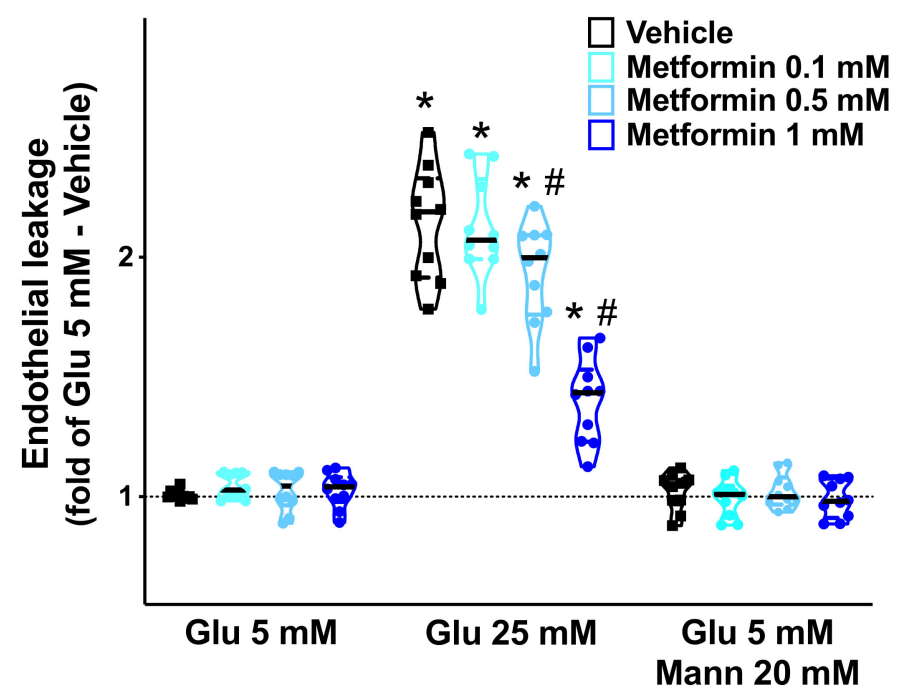

Figure 4. Effects of metformin on endothelial permeability. We assessed the dose-response relationship of metformin on the leakage of human brain microvascular endothelial cells, cultured at the indicated conditions (Glu: glucose; Mann: mannitol); * $p<0.05$ vs. Glu 5 mM; \#: $p<0.05$ vs. Vehicle. 

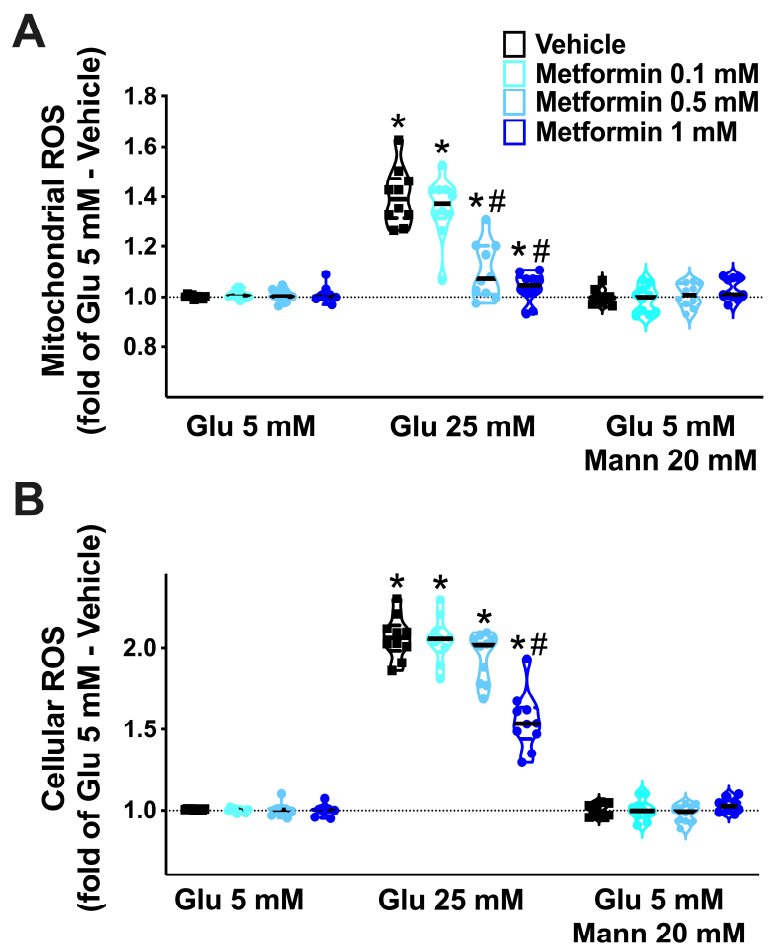

Figure 5. Effects of metformin on the generation of reactive oxygen species (ROS). We evaluated the effects of increasing doses of metformin on the production of mitochondrial (A) and cellular (B) ROS in human brain microvascular endothelial cells cultured at the indicated conditions (Glu: glucose; Mann: mannitol). *: $p<0.05$ vs. Glu 5 mM; \#: $p<0.05$ vs. Vehicle.

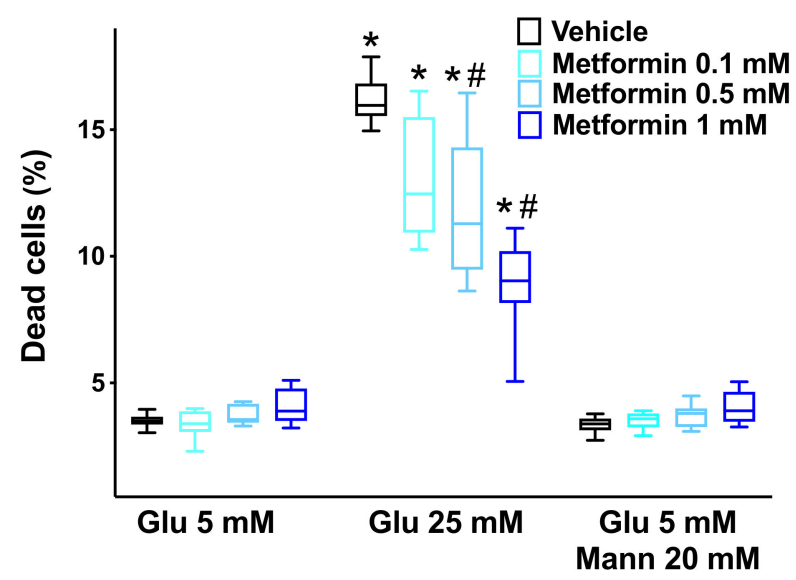

Figure 6. Metformin attenuates high-glucose-induced cell death. By using a luminogenic Caspase$\mathrm{Glo}^{\circledR} 3 / 7$ assay, we evaluated the effects of increasing concentrations of metformin on the apoptosis of human brain microvascular endothelial cells induced by high-glucose (Glu: glucose; Mann: mannitol). The experiments were performed in triplicate. Box plots indicate upper/lower quartiles, the line in the middle of each box is the mean, and the whiskers represent the 5th-95th percentile range of values; *: $p<0.05$ vs. Glu 5 mM; \#: $p<0.05$ vs. Vehicle.

\section{Discussion}

Our results indicate that HG subjects have a lower MoCA score than the NG ones. These data must be contextualized in a frailty condition with hypertension, in which cognitive impairment has a strong impact on functional disability and loss of independence $[66,67]$. The management of frailty in older adults is extremely challenging [68-70] and comorbidities such as hypertension play an instrumental role in increasing the risk of 
mortality, hospitalization, and disability [71,72]. In this scenario, such a delicate balance is heavily disturbed by HG.

Herein, we analyzed the relationship between the MoCA score and glycemia observing a strong correlation ( $\mathrm{r}:-0.611 ; p<0.001)$. To further confirm these results, we performed a linear regression analysis to verify the impact of comorbidities, using the MoCA score as a dependent variable; we found a significant association for age, diabetes, and CVD. Taken together, these data strongly suggest that the achievement of an optimal glycemic control could reduce cognitive impairment in frail and hypertensive older adults.

In this scenario, metformin-treated HG patients presented a better cognitive function than insulin-treated HG patients. These results are consistent with previous reports confirming the beneficial effects of metformin in cognitive impairment [47,73-75]. Other studies have instead shown no significant action [76] or even a detrimental effect [77] of metformin on cognition, although the mechanisms underlying such findings were not explored. These contrasting results could be attributed to several factors, including the disparities in the studied populations. Of note, in our population there were no significant differences between metformin-treated HG patients and NG patients with diabetes, and this aspect strengthens the pivotal role of metformin in counteracting cognitive impairment in our population. Our in vitro results showing a dose-dependent beneficial action of metformin on high-glucose- induced endothelial leakage, oxidative stress, and cell death, provide a molecular mechanism underlying our clinical observations. Of note, these findings are consistent with previous reports [78-87].

Hypertension determines alterations of the endothelium causing oxidative stress, increased vascular permeability, and atherosclerosis [88-91]. We hypothesized that metformin treatment, among its numerous pleiotropic effects [92,93], could attenuate endothelial dysfunction caused by HG, a crucial feature in hypertensive older adults with frailty [94-96]. Furthermore, metformin may modulate and reduce the pathologic mechanisms triggered by insulin resistance $[79,97,98]$. Indeed, metformin has been proposed to be an anti-aging drug and has been associated with a lower risk of frailty in communitydwelling veterans $[99,100]$.

\section{Conclusions}

To the best of our knowledge, this study is the first to correlate MoCA score and glycemia in frail and hypertensive older adults, showing that HG significantly exacerbates cognitive impairment in this class of patients. Although we found beneficial effects of metformin treatment, future dedicated studies with larger samples and longer follow-up are required to confirm our results.

Author Contributions: Conceptualization, P.M., A.P., and G.S.; methodology, P.M., J.G., A.P.; and G.S.; validation, P.M.; formal analysis, P.M., J.G., and G.S.; investigation, P.M., A.P., A.d.D., G.M., E.B., A.M., S.F., and G.S.; data curation, P.M.; writing—original draft preparation, P.M.; writing—review and editing, G.S. All authors have read and agreed to the published version of the manuscript.

Funding: The Santulli's Lab is supported in part by the National Institutes of Health (NIH: R01DK123259, R01-HL159062, R01-DK033823, R01-HL146691, R56-AG066431, T32-HL144456, and R00DK107895, to G.S.), by the Irma T. Hirschl and Monique Weill-Caulier Trusts (to G.S.) and by the American Heart Association (AHA-20POST35211151 to J.G.).

Institutional Review Board Statement: The study was conducted according to the Declaration of Helsinki and approved (\#268) by the Institutional Review Board (Campania University). The Ethical approval has been obtained on 30 September 2016.

Informed Consent Statement: Informed consent was obtained from all subjects involved in the study.

Data Availability Statement: All data are contained within the article.

Conflicts of Interest: The authors declare no conflict of interest. 


\section{References}

1. Iadecola, C.; Duering, M.; Hachinski, V.; Joutel, A.; Pendlebury, S.T.; Schneider, J.A.; Dichgans, M. Vascular Cognitive Impairment and Dementia: Jacc Scientific Expert Panel. J. Am. Coll. Cardiol. 2019, 73, 3326-3344. [CrossRef] [PubMed]

2. Mantovani, E.; Zucchella, C.; Schena, F.; Romanelli, M.G.; Venturelli, M.; Tamburin, S. Towards a Redefinition of Cognitive Frailty. J. Alzheimer's Dis. 2020, 76, 831-843. [CrossRef] [PubMed]

3. Ruan, Q.; D'Onofrio, G.; Sancarlo, D.; Greco, A.; Lozupone, M.; Seripa, D.; Panza, F.; Yu, Z. Emerging biomarkers and screening for cognitive frailty. Aging Clin. Exp. Res. 2017, 29, 1075-1086. [CrossRef] [PubMed]

4. Satizabal, C.L.; Beiser, A.; Chouraki, V.; Chêne, G.; Dufouil, C.; Seshadri, S. Incidence of Dementia over Three Decades in the Framingham Heart Study. N. Engl. J. Med. 2016, 374, 523-532. [CrossRef]

5. Santisteban, M.M.; Ahn, S.J.; Lane, D.; Faraco, G.; Garcia-Bonilla, L.; Racchumi, G.; Poon, C.; Schaeffer, S.; Segarra, S.G.; Körbelin, J.; et al. Endothelium-Macrophage Crosstalk Mediates Blood-Brain Barrier Dysfunction in Hypertension. Hypertension 2020, 76, 795-807. [CrossRef]

6. De Montgolfier, O.; Pinçon, A.; Pouliot, P.; Gillis, M.-A.; Bishop, J.; Sled, J.G.; Villeneuve, L.; Ferland, G.; Lévy, B.I.; Lesage, F.; et al. High Systolic Blood Pressure Induces Cerebral Microvascular Endothelial Dysfunction, Neurovascular Unit Damage, and Cognitive Decline in Mice. Hypertension 2019, 73, 217-228. [CrossRef]

7. Panza, F.; Seripa, D.; Solfrizzi, V.; Tortelli, R.; Greco, A.; Pilotto, A.; Logroscino, G. Targeting Cognitive Frailty: Clinical and Neurobiological Roadmap for a Single Complex Phenotype. J. Alzheimer's Dis. 2015, 47, 793-813. [CrossRef]

8. Wallace, L.M.K.; Theou, O.; Godin, J.; Andrew, M.K.; A Bennett, D.; Rockwood, K. Investigation of frailty as a moderator of the relationship between neuropathology and dementia in Alzheimer's disease: A cross-sectional analysis of data from the Rush Memory and Aging Project. Lancet Neurol. 2019, 18, 177-184. [CrossRef]

9. Wallace, S.M.; Yasmin; McEniery, C.M.; Maki-Petaja, K.M.; Booth, A.D.; Cockcroft, J.R.; Wilkinson, I.B. Isolated Systolic Hypertension Is Characterized by Increased Aortic Stiffness and Endothelial Dysfunction. Hypertension 2007, 50, 228-233. [CrossRef]

10. Panza, J.A.; Quyyumi, A.A.; Brush, J.E., Jr.; Epstein, S.E. Abnormal Endothelium-Dependent Vascular Relaxation in Patients with Essential Hypertension. N. Engl. J. Med. 1990, 323, 22-27. [CrossRef]

11. Santulli, G.; Cipolletta, E.; Sorriento, D.; Del Giudice, C.; Anastasio, A.; Monaco, S.; Maione, A.S.; Condorelli, G.; Puca, A.; Trimarco, B.; et al. CaMK4 Gene Deletion Induces Hypertension. J. Am. Heart Assoc. 2012, 1, e001081. [CrossRef] [PubMed]

12. Gambardella, J.; Coppola, A.; Izzo, R.; Fiorentino, G.; Trimarco, B.; Santulli, G. Role of Endothelial miR-24 in COVID-19 Cerebrovascular Events. Crit. Care 2021, in press.

13. Moreno, P.R.; Purushothaman, K.R.; Fuster, V.; O'Connor, W.N. Intimomedial Interface Damage and Adventitial Inflammation Is Increased beneath Disrupted Atherosclerosis in the Aorta: Implications for Plaque Vulnerability. Circulation 2002, 105, $2504-2511$. [CrossRef] [PubMed]

14. Santulli, G.; Trimarco, B.; Iaccarino, G. G-Protein-Coupled Receptor Kinase 2 and Hypertension: Molecular Insights and Pathophysiological Mechanisms. High Blood Press Cardiovasc. Prev. 2013, 20, 5-12. [CrossRef] [PubMed]

15. Shimbo, D.; Muntner, P.; Mann, D.; Viera, A.J.; Homma, S.; Polak, J.F.; Barr, R.G.; Herrington, D.; Shea, S.J.C. Endothelial Dysfunction and the Risk of Hypertension: The Multi-Ethnic Study of Atherosclerosis. Hypertension 2010, 55, 1210-1216. [CrossRef] [PubMed]

16. Yuan, Q.; Yang, J.; Santulli, G.; Reiken, S.R.; Wronska, A.; Kim, M.M.; Osborne, B.W.; Lacampagne, A.; Yin, Y.; Marks, A.R. Maintenance of Normal Blood Pressure Is Dependent on Ip3r1-Mediated Regulation of Enos. Proc. Natl. Acad. Sci. USA 2016, 113, 8532-8537. [CrossRef] [PubMed]

17. Duckworth, W.C. Hyperglycemia and cardiovascular disease. Curr. Atheroscler. Rep. 2001, 3, 383-391. [CrossRef] [PubMed]

18. Petrie, J.R.; Guzik, T.J.; Touyz, R.M. Diabetes, Hypertension, and Cardiovascular Disease: Clinical Insights and Vascular Mechanisms. Can. J. Cardiol. 2018, 34, 575-584. [CrossRef]

19. Mone, P.; Gambardella, J.; Minicucci, F.; Lombardi, A.; Mauro, C.; Santulli, G. Hyperglycemia Drives Stent Restenosis in Stemi Patients. Diabetes Care 2021, in press.

20. Avogaro, A.; Albiero, M.; Menegazzo, L.; De Kreutzenberg, S.; Fadini, G.P. Endothelial Dysfunction in Diabetes: The role of reparatory mechanisms. Diabetes Care 2011, 34, S285-S290. [CrossRef]

21. Parrinello, C.M.; Hua, S.; Carnethon, M.; Gallo, L.C.; Hudson, B.; Goldberg, R.B.; Delamater, A.M.; Kaplan, R.C.; Isasi, C.R. Associations of hyperglycemia and insulin resistance with biomarkers of endothelial dysfunction in Hispanic/Latino youths: Results from the Hispanic Community Children's Health Study/Study of Latino Youth (SOL Youth). J. Diabetes Complicat. 2017, 31, 836-842. [CrossRef] [PubMed]

22. Adams, J.A.; Lopez, J.R.; Banderas, V.; Sackner, M.A. A single arm trial using passive simulated jogging for blunting acute hyperglycemia. Sci. Rep. 2021, 11, 1-8. [CrossRef]

23. Meza, C.A.; La Favor, J.D.; Kim, D.-H.; Hickner, R.C. Endothelial Dysfunction: Is There a Hyperglycemia-Induced Imbalance of NOX and NOS? Int. J. Mol. Sci. 2019, 20, 3775. [CrossRef] [PubMed]

24. Price, K.D.; Price, C.S.; Reynolds, R.D. Hyperglycemia-induced ascorbic acid deficiency promotes endothelial dysfunction and the development of atherosclerosis. Atherosclerosis 2001, 158, 1-12. [CrossRef]

25. Jafar, N.; Edriss, H.; Nugent, K. The Effect of Short-Term Hyperglycemia on the Innate Immune System. Am. J. Med. Sci. 2016, 351, 201-211. [CrossRef] [PubMed] 
26. Tanaka, J.; Qiang, L.; Banks, A.S.; Welch, C.L.; Matsumoto, M.; Kitamura, T.; Ido-Kitamura, Y.; DePinho, R.; Accili, M. Foxo1 Links Hyperglycemia to LDL Oxidation and Endothelial Nitric Oxide Synthase Dysfunction in Vascular Endothelial Cells. Diabetes 2009, 58, 2344-2354. [CrossRef]

27. Ye, L.; Guo, H.; Wang, Y.; Peng, Y.; Zhang, Y.; Li, S.; Yang, M.; Wang, L. Exosomal circEhmt1 Released from Hypoxia-Pretreated Pericytes Regulates High Glucose-Induced Microvascular Dysfunction via the NFIA/NLRP3 Pathway. Oxidative Med. Cell. Longev. 2021, 2021, 1-13. [CrossRef]

28. Loader, J.; Montero, D.; Lorenzen, C.; Watts, R.; Meziat, C.; Reboul, C.; Stewart, S.; Walther, G. Acute Hyperglycemia Impairs Vascular Function in Healthy and Cardiometabolic Diseased Subjects: Systematic Review and Meta-Analysis. Arterioscler. Thromb. Vasc. Biol. 2015, 35, 2060-2072. [CrossRef]

29. Jankauskas, S.S.; Gambardella, J.; Sardu, C.; Lombardi, A.; Santulli, G. Functional role of miR-155 in the pathogenesis of diabetes mellitus and its complications. Noncoding RNA 2021, 7, 39. [CrossRef]

30. Nieuwdorp, M.; Van Haeften, T.W.; Gouverneur, M.C.L.G.; Mooij, H.L.; Van Lieshout, M.H.P.; Levi, M.; Meijers, J.C.M.; Holleman, F.; Hoekstra, J.B.L.; Vink, H.; et al. Loss of Endothelial Glycocalyx During Acute Hyperglycemia Coincides With Endothelial Dysfunction and Coagulation Activation In Vivo. Diabetes 2006, 55, 480-486. [CrossRef] [PubMed]

31. Stirban, A.; Negrean, M.; Stratmann, B.; Gawlowski, T.; Horstmann, T.; Götting, C.; Kleesiek, K.; Mueller-Roesel, M.; Koschinsky, T.; Uribarri, J.; et al. Benfotiamine Prevents Macro- and Microvascular Endothelial Dysfunction and Oxidative Stress Following a Meal Rich in Advanced Glycation End Products in Individuals With Type 2 Diabetes. Diabetes Care 2006, 29, 2064-2071. [CrossRef]

32. Hung, Y.-J.; Lee, C.-H.; Chu, N.-F.; Shieh, Y.-S. Plasma Protein Growth Arrest-Specific 6 Levels Are Associated With Altered Glucose Tolerance, Inflammation, and Endothelial Dysfunction. Diabetes Care 2010, 33, 1840-1844. [CrossRef]

33. Wleklik, M.; Uchmanowicz, I.; Jankowska, E.A.; Vitale, C.; Lisiak, M.; Drozd, M.; Pobrotyn, P.; Tkaczyszyn, M.; Lee, C. Multidimensional Approach to Frailty. Front. Psychol. 2020, 11, 564. [CrossRef]

34. Mone, P.; Gambardella, J.; Pansini, A.; Rizzo, M.; Mauro, C.; Minicucci, F.; Santulli, G. Impact of thrombus aspiration in frail STEMI patients. Aging Clin. Exp. Res. 2021, 1-9. [CrossRef]

35. Lee, D.H.; Buth, K.J.; Martin, B.-J.; Yip, A.; Hirsch, G.M. Frail Patients Are at Increased Risk for Mortality and Prolonged Institutional Care After Cardiac Surgery. Circulation 2010, 121, 973-978. [CrossRef]

36. Solfrizzi, V.; Scafato, E.; Lozupone, M.; Seripa, D.; Schilardi, A.; Custodero, C.; Sardone, R.; Galluzzo, L.; Gandin, C.; Baldereschi, M.; et al. Biopsychosocial frailty and the risk of incident dementia: The Italian longitudinal study on aging. Alzheimer's Dement. 2019, 15, 1019-1028. [CrossRef] [PubMed]

37. Fried, L.P.; Tangen, C.M.; Walston, J.; Newman, A.B.; Hirsch, C.; Gottdiener, J.; Seeman, T.; Tracy, R.; Kop, W.J.; Burke, G.; et al Frailty in Older Adults: Evidence for a Phenotype. J. Gerontol. Ser. Biol. Sci. Med. Sci. 2001, 56, M146-M157. [CrossRef] [PubMed]

38. Clegg, A.; Hassan-Smith, Z. Frailty and the endocrine system. Lancet Diabetes Endocrinol. 2018, 6, 743-752. [CrossRef]

39. Clegg, A.; Young, J.; Iliffe, S.; Rikkert, M.O.; Rockwood, K. Frailty in elderly people. Lancet 2013, 381, 752-762. [CrossRef]

40. Rockwood, K.; Stadnyk, K.; MacKnight, C.; McDowell, I.; Hébert, R.; Hogan, D. A brief clinical instrument to classify frailty in elderly people. Lancet 1999, 353, 205-206. [CrossRef]

41. Hanlon, P.; I Nicholl, B.; Jani, B.D.; Lee, D.; McQueenie, R.; Mair, F.S. Frailty and pre-frailty in middle-aged and older adults and its association with multimorbidity and mortality: A prospective analysis of 493737 UK Biobank participants. Lancet Public Health 2018, 3, e323-e332. [CrossRef]

42. Mone, P.; Pansini, A. Gait Speed Test and Cognitive Decline in Frail Women With Acute Myocardial Infarction. Am. J. Med. Sci. 2020, 360, 484-488. [CrossRef]

43. Pedone, C.; Costanzo, L.; Cesari, M.; Bandinelli, S.; Ferrucci, L.; Incalzi, R.A. Are Performance Measures Necessary to Predict Loss of Independence in Elderly People? J. Gerontol. Ser. A Boil. Sci. Med. Sci. 2015, 71, 84-89. [CrossRef] [PubMed]

44. Chaudhari, K.; Reynolds, C.D.; Yang, S.-H. Metformin and cognition from the perspectives of sex, age, and disease. GeroScience 2020, 42, 97-116. [CrossRef] [PubMed]

45. Melissa, A.Y.; Maruschak, N.; Mansur, R.; Carvalho, A.F.; Cha, D.S.; McIntyre, R.S. Metformin: Repurposing Opportunities for Cognitive and Mood Dysfunction. CNS Neurol. Disord. Drug Targets 2015, 13, 1836-1845. [CrossRef]

46. Nafisa, A.; Gray, S.G.; Cao, Y.; Wang, T.; Xu, S.; Wattoo, F.H.; Barras, M.; Cohen, N.; Kamato, D.; Little, P.J. Endothelial function and dysfunction: Impact of metformin. Pharmacol. Ther. 2018, 192, 150-162. [CrossRef] [PubMed]

47. Ng, T.P.; Feng, L.; Yap, K.B.; Lee, T.S.; Tan, C.H.; Winblad, B. Long-Term Metformin Usage and Cognitive Function among Older Adults with Diabetes. J. Alzheimer's Dis. 2014, 41, 61-68. [CrossRef] [PubMed]

48. Luchsinger, J.A.; Perez, T.; Chang, H.; Mehta, P.; Steffener, J.; Pradabhan, G.; Ichise, M.; Manly, J.; Devanand, D.P.; Bagiella, E. Metformin in Amnestic Mild Cognitive Impairment: Results of a Pilot Randomized Placebo Controlled Clinical Trial. J. Alzheimer's Dis. 2016, 51, 501-514. [CrossRef]

49. Samaras, K.; Makkar, S.; Crawford, J.D.; Kochan, N.A.; Wen, W.; Draper, B.; Trollor, J.N.; Brodaty, H.; Sachdev, P.S. Metformin Use Is Associated With Slowed Cognitive Decline and Reduced Incident Dementia in Older Adults With Type 2 Diabetes: The Sydney Memory and Ageing Study. Diabetes Care 2020, 43, 2691-2701. [CrossRef]

50. Tumminia, A.; Vinciguerra, F.; Parisi, M.; Frittitta, L. Type 2 Diabetes Mellitus and Alzheimer's Disease: Role of Insulin Signalling and Therapeutic Implications. Int. J. Mol. Sci. 2018, 19, 3306. [CrossRef] [PubMed]

51. Cioce, M.; Pulito, C.; Strano, S.; Blandino, G.; Fazio, V.M. Metformin: Metabolic Rewiring Faces Tumor Heterogeneity. Cells 2020, 9, 2439. [CrossRef] [PubMed] 
52. Yarchoan, M.; Arnold, S.E. Repurposing Diabetes Drugs for Brain Insulin Resistance in Alzheimer Disease. Diabetes 2014, 63, 2253-2261. [CrossRef]

53. Buse, J.B.; Wexler, D.J.; Tsapas, A.; Rossing, P.; Mingrone, G.; Mathieu, C.; D’Alessio, D.A.; Davies, M.J. 2019 Update To: Management of Hyperglycemia in Type 2 Diabetes, A Consensus Report by the American Diabetes Association (Ada) and the European Association for the Study of Diabetes (Easd). Diabetes Care 2020, 43, 487-493. [CrossRef]

54. Unger, T.; Borghi, C.; Charchar, F.; Khan, N.A.; Poulter, N.R.; Prabhakaran, D.; Ramirez, A.; Schlaich, M.; Stergiou, G.S.; Tomaszewski, M.; et al. 2020 International Society of Hypertension Global Hypertension Practice Guidelines. Hypertension 2020, 75, 1334-1357. [CrossRef] [PubMed]

55. Pinto, T.C.C.; Machado, L.; Bulgacov, T.M.; Rodrigues-Júnior, A.L.; Costa, M.L.G.; Ximenes, R.C.C.; Sougey, E.B. Is the Montreal Cognitive Assessment (MoCA) screening superior to the Mini-Mental State Examination (MMSE) in the detection of mild cognitive impairment (MCI) and Alzheimer's Disease (AD) in the elderly? Int. Psychogeriatr. 2018, 31, 491-504. [CrossRef]

56. O'Driscoll, C.; Shaikh, M. Cross-Cultural Applicability of the Montreal Cognitive Assessment (MoCA): A Systematic Review. J. Alzheimer's Dis. 2017, 58, 789-801. [CrossRef]

57. Nasreddine, Z.S.; Phillips, N.A.; Bédirian, V.; Charbonneau, S.; Whitehead, V.; Collin, I.; Cummings, J.L.; Chertkow, H. The Montreal Cognitive Assessment, MoCA: A Brief Screening Tool For Mild Cognitive Impairment. J. Am. Geriatr. Soc. 2005, 53, 695-699. [CrossRef] [PubMed]

58. Mone, P.; Gambardella, J.; Wang, X.; Jankauskas, S.S.; Matarese, A.; Santulli, G. miR-24 Targets the Transmembrane Glycoprotein Neuropilin-1 in Human Brain Microvascular Endothelial Cells. Non-Coding RNA 2021, 7, 9. [CrossRef] [PubMed]

59. Gambardella, J.; Sorriento, D.; Bova, M.; Rusciano, M.; Loffredo, S.; Wang, X.; Petraroli, A.; Carucci, L.; Mormile, I.; Oliveti, M.; et al. Role of Endothelial G Protein-Coupled Receptor Kinase 2 in Angioedema. Hypertension 2020, 76, 1625-1636. [CrossRef]

60. Santulli, G.; Xie, W.; Reiken, S.R.; Marks, A.R. Mitochondrial Calcium Overload Is a Key Determinant in Heart Failure. Proc. Natl. Acad. Sci. USA 2015, 112, 11389-11394. [CrossRef]

61. Xie, W.; Santulli, G.; Reiken, S.R.; Yuan, Q.; Osborne, B.W.; Chen, B.X.; Marks, A.R. Mitochondrial Oxidative Stress Promotes Atrial Fibrillation. Sci. Rep. 2015, 5, 11427. [CrossRef]

62. Amgalan, D.; Garner, T.P.; Pekson, R.; Jia, X.F.; Yanamandala, M.; Paulino, V.; Liang, F.G.; Corbalan, J.J.; Lee, J.; Chen, Y.; et al. A small-molecule allosteric inhibitor of BAX protects against doxorubicin-induced cardiomyopathy. Nat. Rev. Cancer 2020, 1, 315-328. [CrossRef]

63. Hempel, A.; Maasch, C.; Heintze, U.; Lindschau, C.; Dietz, R.; Luft, F.C.; Haller, H. High glucose concentrations increase endothelial cell permeability via activation of protein kinase C alpha. Circ. Res. 1997, 81, 363-371. [CrossRef]

64. Meredith, M.E.; Qu, Z.-C.; May, J.M. Ascorbate reverses high glucose- and RAGE-induced leak of the endothelial permeability barrier. Biochem. Biophys. Res. Commun. 2014, 445, 30-35. [CrossRef]

65. Kida, T.; Oku, H.; Osuka, S.; Horie, T.; Ikeda, T. Hyperglycemia-induced VEGF and ROS production in retinal cells is inhibited by the mTOR inhibitor, rapamycin. Sci. Rep. 2021, 11, 1-9. [CrossRef]

66. Aliberti, M.J.R.; Szlejf, C.; Lima-Costa, M.F.; de Andrade, F.B.; Alexandre, T.S.; Ferri, C.P.; Suemoto, C.K. Frailty Modifies the Association of Hypertension With Cognition in Older Adults: Evidence From the ELSI-Brazil. J. Gerontol. Ser. A Boil. Sci. Med. Sci. 2021, 76, 1134-1143. [CrossRef]

67. Lee, J.S.W.; Auyeung, T.-W.; Leung, J.; Kwok, T.; Leung, P.-C.; Woo, J. Physical frailty in older adults is associated with metabolic and atherosclerotic risk factors and cognitive impairment independent of muscle mass. J. Nutr. Health Aging 2011, 15, 857-862. [CrossRef]

68. Quach, L.T.; Primack, J.; Bozzay, M.; Madrigal, C.; Erqou, S.; Rudolph, J.L. The Intersection of Physical and Social Frailty in Older Adults. Rhode Isl. Med. J. 2021, 104, 16-19.

69. Rezaei-Shahsavarloo, Z.; Atashzadeh-Shoorideh, F.; Gobbens, R.J.J.; Ebadi, A.; Harouni, G.G. The impact of interventions on management of frailty in hospitalized frail older adults: A systematic review and meta-analysis. BMC Geriatr. 2020, 20, 1-17. [CrossRef] [PubMed]

70. Negm, A.; Kennedy, C.C.; Thabane, L.; Veroniki, A.-A.; Adachi, J.D.; Richardson, J.; Cameron, I.D.; Giangregorio, A.; Petropoulou, M.; Alsaad, S.M.; et al. Management of Frailty: A Systematic Review and Network Meta-analysis of Randomized Controlled Trials. J. Am. Med. Dir. Assoc. 2019, 20, 1190-1198. [CrossRef]

71. Camafort, M.; Kario, K. Hypertension, heart failure, and frailty in older people: A common but unclear situation. J. Clin. Hypertens. 2020, 22, 1763-1768. [CrossRef] [PubMed]

72. Liu, P.; Li, Y.; Zhang, Y.; Mesbah, S.E.; Ji, T.; Ma, L. Frailty and hypertension in older adults: Current understanding and future perspectives. Hypertens. Res. 2020, 43, 1352-1360. [CrossRef] [PubMed]

73. Lin, Y.; Wang, K.; Ma, C.; Wang, X.; Gong, Z.; Zhang, R.; Zang, D.; Cheng, Y. Evaluation of Metformin on Cognitive Improvement in Patients with Non-Dementia Vascular Cognitive Impairment and Abnormal Glucose Metabolism. Front. Aging Neurosci. 2018, 10, 227. [CrossRef] [PubMed]

74. Zhang, Q.Q.; Li, W.S.; Liu, Z.; Zhang, H.L.; Ba, Y.G.; Zhang, R.X. Metformin Therapy and Cognitive Dysfunction in Patients with Type 2 Diabetes: A Meta-Analysis and Systematic Review. Medicine 2020, 99, e19378. [CrossRef] [PubMed]

75. Koenig, A.M.; Mechanic-Hamilton, D.; Xie, S.X.; Combs, M.F.; Cappola, A.R.; Xie, L.; Detre, J.A.; Wolk, D.A.; Arnold, S.E. Effects of the Insulin Sensitizer Metformin in Alzheimer Disease: Pilot Data from a Randomized Placebo-Controlled Crossover Study. Alzheimer Dis. Assoc. Disord. 2017, 31, 107-113. [CrossRef] [PubMed] 
76. Luchsinger, J.; Ma, Y.; Christophi, C.A.; Florez, H.; Golden, S.H.; Hazuda, H.; Crandall, J.; Venditti, E.; Watson, K.; Jeffries, S.; et al. Metformin, Lifestyle Intervention, and Cognition in the Diabetes Prevention Program Outcomes Study. Diabetes Care 2017, 40, 958-965. [CrossRef] [PubMed]

77. Moore, E.M.; Mander, A.G.; Ames, D.; Kotowicz, M.A.; Carne, R.P.; Brodaty, H.; Woodward, M.; Boundy, K.; Ellis, K.A.; Bush, A.I.; et al. Increased Risk of Cognitive Impairment in Patients With Diabetes Is Associated With Metformin. Diabetes Care 2013, 36, 2981-2987. [CrossRef] [PubMed]

78. Ahmed, F.W.; Rider, R.; Glanville, M.; Narayanan, K.; Razvi, S.; Weaver, J.U. Metformin improves circulating endothelial cells and endothelial progenitor cells in type 1 diabetes: MERIT study. Cardiovasc. Diabetol. 2016, 15, 1-10. [CrossRef]

79. Apostolova, N.; Iannantuoni, F.; Gruevska, A.; Muntane, J.; Rocha, M.; Victor, V.M. Mechanisms of action of metformin in type 2 diabetes: Effects on mitochondria and leukocyte-endothelium interactions. Redox Biol. 2020, 34, 101517. [CrossRef]

80. Arunachalam, G.; Samuel, S.M.; Marei, I.; Ding, H.; Triggle, C. Metformin modulates hyperglycaemia-induced endothelial senescence and apoptosis through SIRT. Br. J. Pharmacol. 2013, 171, 523-535. [CrossRef]

81. Diaz-Morales, N.; Rovira-Llopis, S.; Bañuls, C.; Lopez-Domenech, S.; Escribano-Lopez, I.; Veses, S.; Jover, A.; Rocha, M.; Hernandez-Mijares, A.; Victor, V. Does Metformin Protect Diabetic Patients from Oxidative Stress and Leukocyte-Endothelium Interactions? Antioxid. Redox Signal. 2017, 27, 1439-1445. [CrossRef] [PubMed]

82. Detaille, D.; Guigas, B.; Chauvin, C.; Batandier, C.; Fontaine, E.; Wiernsperger, N.; Leverve, X. Metformin Prevents HighGlucose-Induced Endothelial Cell Death Through a Mitochondrial Permeability Transition-Dependent Process. Diabetes 2005, 54, 2179-2187. [CrossRef] [PubMed]

83. Batchuluun, B.; Inoguchi, T.; Sonoda, N.; Sasaki, S.; Inoue, T.; Fujimura, Y.; Miura, D.; Takayanagi, R. Metformin and liraglutide ameliorate high glucose-induced oxidative stress via inhibition of PKC-NAD $(\mathrm{P}) \mathrm{H}$ oxidase pathway in human aortic endothelial cells. Atherosclerosis 2014, 232, 156-164. [CrossRef] [PubMed]

84. Bharath, L.P.; Agrawal, M.; McCambridge, G.; Nicholas, D.A.; Hasturk, H.; Liu, J.; Jiang, K.; Liu, R.; Guo, Z.; Deeney, J.; et al. Metformin Enhances Autophagy and Normalizes Mitochondrial Function to Alleviate Aging-Associated Inflammation. Cell Metab. 2020, 32, 44-55. [CrossRef] [PubMed]

85. Salvatore, T.; Pafundi, P.C.; Galiero, R.; Rinaldi, L.; Caturano, A.; Vetrano, E.; Aprea, C.; Albanese, G.; Di Martino, A.; Ricozzi, C.; et al. Can Metformin Exert as an Active Drug on Endothelial Dysfunction in Diabetic Subjects? Biomedicines 2020, 9, 3. [CrossRef]

86. Cheang, W.S.; Tian, X.Y.; Wong, W.T.; Lau, C.W.; Lee, S.S.; Chen, Z.Y.; Yao, X.; Wang, N.; Huang, Y. Metformin Protects Endothelial Function in Diet-Induced Obese Mice by Inhibition of Endoplasmic Reticulum Stress through 5' Adenosine MonophosphateActivated Protein Kinase-Peroxisome Proliferator-Activated Receptor Delta Pathway. Arter. Thromb. Vasc. Biol. 2014, 34, 830-836. [CrossRef]

87. Tao, L.; Fan, X.; Sun, J.; Zhang, Z. Metformin Prevented High Glucose-Induced Endothelial Reactive Oxygen Species Via Ogg1 in an Ampkalpha-Lin-28 Dependent Pathway. Life Sci. 2021, 268, 119015. [CrossRef]

88. Touyz, R.M.; Rios, F.J.; Alves-Lopes, R.; Neves, K.B.; Camargo, L.D.L.; Montezano, A.C. Oxidative Stress: A Unifying Paradigm in Hypertension. Can. J. Cardiol. 2020, 36, 659-670. [CrossRef]

89. Buford, T.W. Hypertension and aging. Ageing Res. Rev. 2016, 26, 96-111. [CrossRef]

90. Watson, T.; Goon, P.K.; Lip, G.Y. Endothelial Progenitor Cells, Endothelial Dysfunction, Inflammation, and Oxidative Stress in Hypertension. Antioxid. Redox Signal. 2008, 10, 1079-1088. [CrossRef]

91. Chaudhary, P.; Pandey, A.; Azad, C.S.; Tia, N.; Singh, M.; Gambhir, I.S. Association of oxidative stress and endothelial dysfunction in hypertension. Anal. Biochem. 2020, 590, 113535. [CrossRef]

92. Barzilai, N.; Crandall, J.P.; Kritchevsky, S.B.; Espeland, M.A. Metformin as a Tool to Target Aging. Cell Metab. 2016, 23, 1060-1065. [CrossRef]

93. Novelle, M.G.; Ali, A.; Diéguez, C.; Bernier, M.; De Cabo, R. Metformin: A Hopeful Promise in Aging Research. Cold Spring Harb. Perspect. Med. 2016, 6, a025932. [CrossRef] [PubMed]

94. Benetos, A.; Petrovic, M.; Strandberg, T. Hypertension Management in Older and Frail Older Patients. Circ. Res. 2019, 124, 1045-1060. [CrossRef] [PubMed]

95. Gambardella, J.; Khondkar, W.; Morelli, M.B.; Wang, X.; Santulli, G.; Trimarco, V. Arginine and Endothelial Function. Biomedicines 2020, 8, 277. [CrossRef] [PubMed]

96. Alonso-Bouzón, C.; Carcaillon, L.; Garcia-Garcia, F.J.; Amor-Andrés, M.S.; El Assar, M.; Rodríguez-Mañas, L. Association between endothelial dysfunction and frailty: The Toledo Study for Healthy Aging. Age 2014, 36, 495-505. [CrossRef] [PubMed]

97. Espinoza, S.; Musi, N.; Wang, C.-P.; Michalek, J.; Orsak, B.; Romo, T.; Powers, B.; Conde, A.; Moris, M.; Bair-Kelps, D.; et al. Rationale and Study Design of a Randomized Clinical Trial of Metformin to Prevent Frailty in Older Adults With Prediabetes. J. Gerontol. Ser. A Boil. Sci. Med. Sci. 2020, 75, 102-109. [CrossRef]

98. Wang, C.-P.; Lorenzo, C.; Habib, S.L.; Jo, B.; Espinoza, S.E. Differential effects of metformin on age related comorbidities in older men with type 2 diabetes. J. Diabetes Complicat. 2017, 31, 679-686. [CrossRef]

99. Glossmann, H.H.; Lutz, O.M. Metformin and Aging: A Review. Gerontology 2019, 65, 581-590. [CrossRef]

100. Baskaran, D.; Aparicio-Ugarriza, R.; Ferri-Guerra, J.; Milyani, R.; Florez, H.; Ruiz, J.G. Is There an Association Between Metformin Exposure and Frailty? Gerontol. Geriatr. Med. 2020, 6, 2333721420924956. [CrossRef] 